\title{
Credit reporting, relationship banking, and loan repayment
}

\author{
Tahereh Shirzad Kebria* and Ali Aalikhani
}

Department of Management, Tehran North Branch, Islamic Azad University, Tehran, Iran

\begin{tabular}{l}
\hline C H R O N I C L E \\
\hline Article history: \\
Received January 20, 2015 \\
Received in revised format 16 \\
February 2015 \\
Accepted 18 April 2015 \\
Available online \\
April 20 2015 \\
\hline Keywords: \\
Loan \\
Repayment \\
Bank
\end{tabular}
A B S T R A C T

\begin{abstract}
This paper presents an empirical investigation to determine factors influencing on loan repayment in one of Iranian banks named Sepah Bank over the period 2012-2013. The study selects a sample of 290 bank's customers who received loans and, using logistic regression technique, tries to find whether or not qualitative as well as quantitative characteristics of loan receivers influence on repayment of loans. The results indicate that history of outstanding debt as well as customers' past experiences with banks had meaningful relationships with having bad credit and non-payment of loans. In our survey, having a bad credit in the past had positive relationship with non-payment of loans but long-term customers had negative relationship with non-payment of loans. In addition, working capital turnover ratio, cash ratio, total liabilities, current assets and loan value had significant impact on non-repayment of the loan facilities.
\end{abstract}

\section{Introduction}

Many people are normally forced to make difficult decisions every day about paying bills, buying food, accessing medical care, and stretching their household budgets. Business activities and banks are designed to make it easier for people to connect with programs and resources that can make such decisions just easier. Banks keep people's saving and create opportunities for online purchase without carrying cash. Banks, on the other hands, use deposits to give loans to firms, business owners, etc. The primary question is to find out more about factors influencing repayment loans (Cassar et al., 2007). Lending to the worlds' poor through groups rather than individuals is also used as a tool to reduce poverty (Paxton et al., 2000). Salleh et al. (2014) performed an investigation to find out whether an interest-free credit facility is more efficient than a usurious payday loan. Sharma and Zeller (1997) investigated the repayment rates of 128 credit groups associated with three group-based credit programs in Bangladesh. Using TOBIT analysis, specific experiments were executed on group size, size of loans, degree of loan rationing, enterprise mix within groups, demographic characteristics, social ties and status, and occurrence of idiosyncratic shocks. They reported that whenever some basic principles of prudential banking were adhered to, repayment rates could be good even in poor and remote communities.

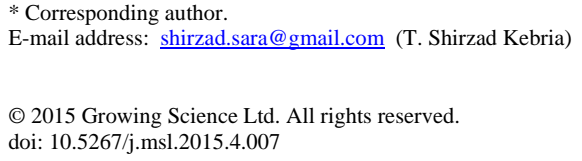


According to Brown and Zehnder (2007), information sharing may increase repayment rates, as borrowers forecast that a good credit record definitely may contribute their access to credit. This incentive effect of information sharing is significant when repayment is not third-party enforceable and lending is dominated by one-shot transactions. Onyenucheya and Ukoha (2007) determined the factors influencing loan repayment of farmers in Nigeria. They reported that amount of loan borrowed, annual income and distance between and loan source were key determinants of repayment. Godquin (2004) presented a comprehensive investigation of the performance of microfinance institutions (MFIs) in terms of repayment. They concentrated on the analysis on the effect of group lending, nonfinancial services and dynamic incentives on repayment performance. They applied a comparative analysis of the determinants of the repayment performance and of loan size to make policy recommendations on the allocation of loans by MFIs. Derban et al. (2005) investigated loan repayment performance in community development finance institutions in the UK. They reported that 8 out of the 13 institutional characteristics examined substantially influence loan repayment performance. Graham et al. (2008) studied the impact of financial restatement on bank loan contracting and reported that compared with loans initiated before restatement, loans initiated after restatement had substantially higher spreads, shorter maturities, higher likelihood of being secured, and more covenant restrictions. In their survey, the increase in loan spread was substantially larger for fraudulent restating companies than other restating ones. They also reported that after restatement, the number of lenders per loan declined and companies paid higher upfront and annual fees. Brehanu and Fufa (2008) used a two-limit Tobit model to study the determinants of repayment rate of loans from semi-formal financial institutions among small-scale farmers in Ethiopia. Small group lending, was reported to be positively associated with the loan repayment rate of the farmers. Cornett et al. (2013) looked at how the pre-crisis health of banks was associated with the probability of receiving and repaying TARP capital. They reported that financial performance characteristics associated with the probability of receiving TARP funds varied for the healthiest against the least healthy banks. They reported that TARP under-achievers had some, but not consistent, weaknesses in income production. Abid et al. (2014) reported that the extent to which households' non-performing loans in the Tunisian banking system could be described particularly not only by macroeconomic variables but also by bad management quality. Majeske and Lauer (2013) studied the bank loan approval decision from multiple perspectives and developed a probability model to assess the predictive validity of two-way classification schemes in the context of personal credit scoring and bank loan applications. Lin et al. (2014) performed an empirical investigation on bank equity risk under bailout programs of loan guarantee and/or equity capital injection.

\section{The proposed study}

This paper presents an empirical investigation to determine factors influencing on loan repayment in one of Iranian banks named Sepah Bank over the period 2012-2013. Fig. 1 demonstrates the structure of the proposed study.

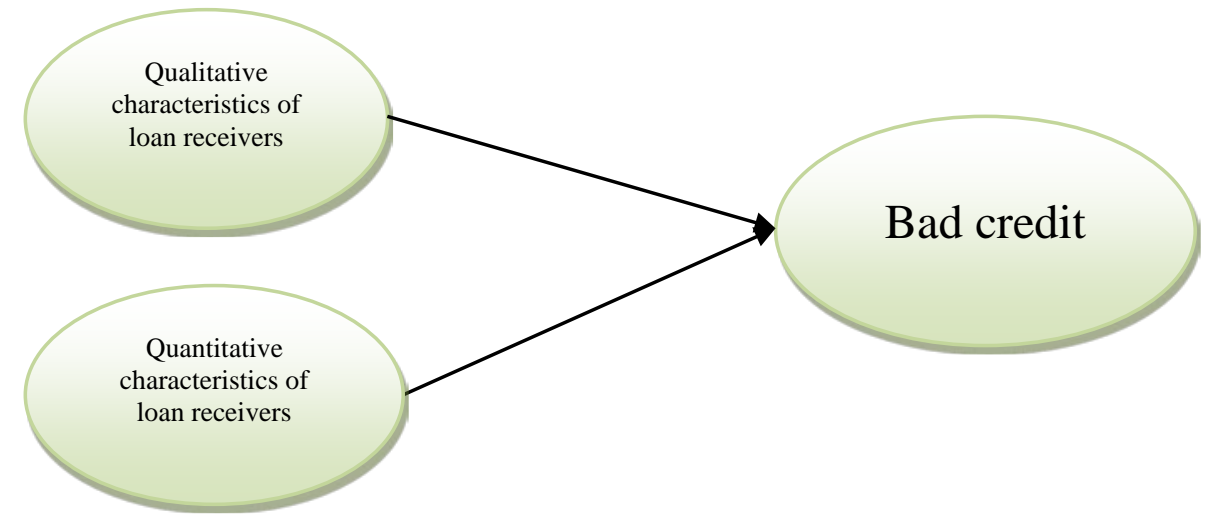

Fig. 1. The structure of the proposed study 
As we can observe from the structure of Fig. 1, the study investigates the effects of two variables on having bad credit. In our study there were 1090 firms received loans from Bank Sepah and the study determines the sample size as follows,

$$
n=\frac{N \times z_{\alpha / 2}^{2} \times p \times q}{\varepsilon^{2} \times(N-1)+z_{\alpha / 2}^{2} \times p \times q},
$$

where $N$ is the population size, $p=1-q$ represents the yes/no categories, $z_{\alpha / 2}$ is CDF of normal distribution and finally $\varepsilon$ is the error term. Since we have $p=0.5, z_{\alpha / 2}=1.96$ and $N=1090$, the number of sample size is calculated as $n=290$. Fig. 2 demonstrates personal charactersitics of the participants.

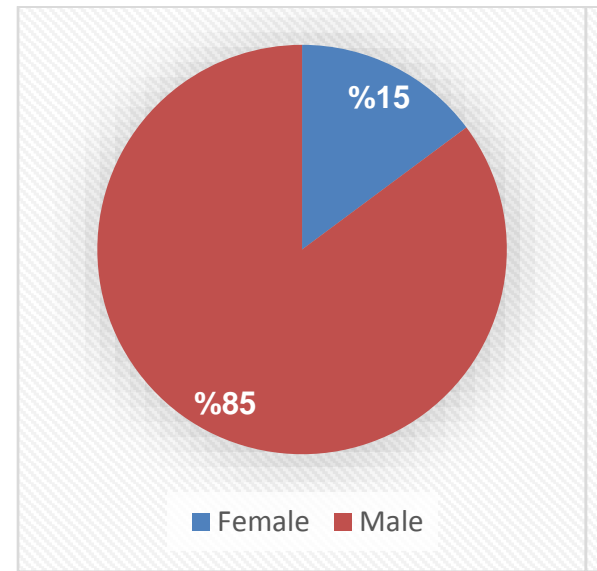

Gender

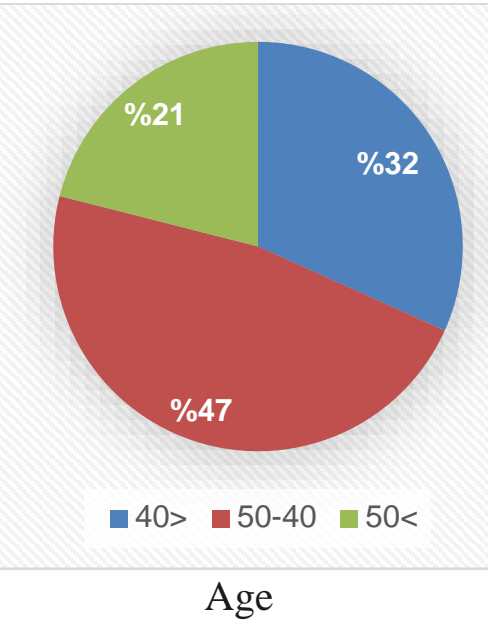

Age

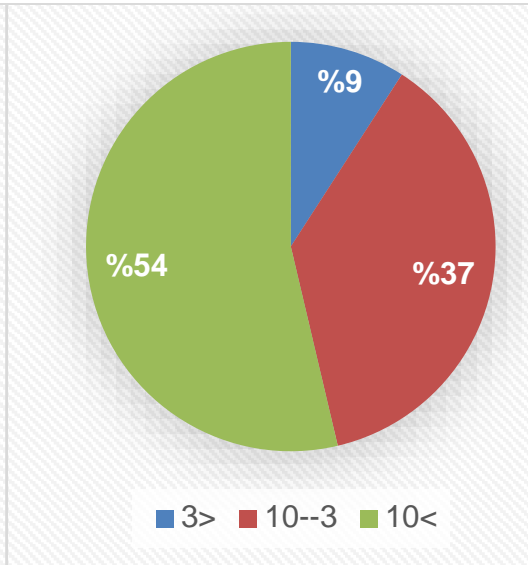

Expertise of work with bank

Fig. 2. Personal characteristics of the participants

In our survey, 106 of participants had bad credit. In addition, 85 percent of the respondents were male, $80 \%$ had at least 40 years of age and $91 \%$ of them maintained, at least, 3 years of cooperation with bank. Table 1 demonstrates the summary of some basic statistics on quantitative data. The table also shows the results of unit root test using the method developed by Im et al. (1997).

\section{Table 1}

The summary of some basic statistics

\begin{tabular}{lccccccc}
\hline Variable & Mean & Median & $\begin{array}{c}\text { Std. } \\
\text { deviation }\end{array}$ & Min & Max & W-stats & P-value \\
\hline Working capital turnover ratio & 3.1304 & 3.1406 & 0.6444 & 2.0205 & 4.2222 & 112.567 & 0.000 \\
Receivable accounts period & 0.3263 & 0.3266 & 0.0602 & 0.2201 & 0.4287 & 33.832 & 0.009 \\
Cash ratio & 0.3267 & 0.3276 & 0.059 & 0.2202 & 0.4289 & 59.543 & 0.0001 \\
Current ratio & 0.3443 & 0 & 0.4754 & 0 & 1 & 21.003 & 0.0015 \\
Ratio of current liabilities to & 0.2758 & 0.2752 & 0.0321 & 0.22 & 0.3289 & 21.809 & 0.000 \\
value added & 0.1047 & 0.118 & 0.1907 & -0.22 & 0.427 & 43.128 & 0.002 \\
Leverage ratio & 120.7 & 110.5 & 20.9 & 19.5 & 950.5 & 77.111 & 0.008 \\
Total liabilities & 450.6 & 550.7 & 20.7 & 110.7 & 400.19 & 21.109 & 0.027 \\
\hline Current assets & 700 & 650 & 119.6 & 120 & 990 & 32.121 & 0.0036 \\
Loan & 112.82 & 113.13 & 6.16 & 102.03 & 122.86 & 10.854 & 0.042 \\
Customers' turnover & 179.627 & 179.5 & 30.2777 & 128 & 234 & 18.131 & 0.012 \\
\hline Mean account & & & & & & & \\
\hline
\end{tabular}


As we can observe from the results of Table 1, all statistics associated with W-stats are meaningful when the level of significance is five percent and we can conclude that they are stationary variables.

\section{The results and discussion}

In this section, we present the results of the implementation of regression function on testing different qualitative and quantitative variables on loan repayment. To examine different factors, the study uses Wald statistics and Table 2 shows details of our findings. In terms of qualitative factors, as we can see from the results of Table 2, while age and gender did not represent meaningful impact on loan repayment, experience of work with bank has shown some meaningful impact on loan repayment. In fact, as customers setup a long term relationship with bank, it is less likely that customers face with bad credit. In other words, banks had better give loans to customers with good record of credit in the past. In terms of quantitative factors, among several financial figures, only the effects of working capital period, leverage ratio, current assets have had positive relationship with loan repayment. In other words, customers with relatively high ratio of loan with banks will more likely face with bad credit. However, when a customer manage to have good record of current assets, customers may be expected to have better capabilities to pay their loans.

Table 2

The summary of regression analysis

\begin{tabular}{lcccccc}
\hline Variables & $\beta$ & Error & Wald & Sig. & Exp(p) & Result \\
\hline Gender & 0.161 & 0.405 & 0.158 & 0.691 & 1.174 & Rejected \\
\hline Age & 0.157 & 0.181 & 0.749 & 0.387 & 1.17 & Rejected \\
Experience of work with bank & -0.209 & 0.097 & 4.609 & 0.037 & 0.801 & Confirmed \\
Having overdue loan & 0.609 & 0.128 & 7.901 & 0.001 & 1.782 & Confirmed \\
Working capital turnover & -0.401 & 0.109 & 4.801 & 0.021 & 0.711 & Confirmed \\
Average payment period & -0.321 & 0.445 & 0.519 & 0.471 & 0.726 & Rejected \\
Cash flow ratio & -0.161 & 0.102 & 4.118 & 0.041 & 0.614 & Rejected \\
Current ratio & -0.148 & 0.226 & 0.432 & 0.511 & 0.862 & Rejected \\
Ratio of current liabilities to & 0.054 & 0.075 & 0.524 & 0.469 & 1.056 & Rejected \\
value added & -0.108 & 0.115 & 0.878 & 0.349 & 0.898 & Rejected \\
\hline Leverage ratio & 0.441 & 0.128 & 4.112 & 0.017 & 1.561 & Confirmed \\
Total liabilities & -0.5 & 0.261 & 3.659 & 0.046 & 0.607 & Confirmed \\
Current assets & 0.64 & 0.248 & 6.678 & 0.01 & 1.527 & Confirmed \\
\hline Loan & 0.29 & 0.229 & 1.6 & 0.206 & 1.337 & Rejected \\
\hline Customers' turnover & -0.023 & 0.276 & 0.007 & 0.934 & 0.977 & Rejected \\
\hline Mean account & 0.112 & 0.017 & 1.416 & 0.234 & 1.102 & Rejected \\
\hline Intercept & & & & &
\end{tabular}

The results of this study are consistent with other existing studies in the literature (Behr \& Sonnekalb, 2012; Hill \& Sarangi, 2012; Chapman \& Liu, 2013; Baland et al., 2013; Vu et al., 2015; Chapman \& Lounkaew, 2015).

\section{Conclusion}

In this paper, we have presented an empirical investigation to study the qualitative/quantitative factors influencing on non-repayment of loans in one of the oldest Iranian banks located in city of Tehran, Iran. In this study, while age and gender did not show any meaningful impacts on loan repayment, experience 
of work with bank has demonstrated some meaningful impact on loan repayment. In fact, customers with long term relationship with bank would less likely faced with bad credit. In other words, banks had better give loans to customers with good record of credit in the past. In terms of quantitative factors, among several financial figures, only the effects of working capital period, leverage ratio, current assets have had positive relationship with loan repayment. In other words, customers with relatively high ratio of loan with banks would more likely face with bad credit. However, when a customer manage to have good record of current assets, customers may be expected to have better capabilities to pay their loans.

\section{Acknowledgement}

The authors would like to thank the anonymous referees for constructive comments on earlier version of this paper.

\section{References}

Abid, L., Ouertani, M. N., \& Zouari-Ghorbel, S. (2014). Macroeconomic and bank-specific determinants of household's non-performing loans in Tunisia: A dynamic panel data. Procedia Economics and Finance, 13, 58-68.

Baland, J. M., Somanathan, R., \& Wahhaj, Z. (2013). Repayment incentives and the distribution of gains from group lending. Journal of Development Economics, 105, 131-139.

Behr, P., \& Sonnekalb, S. (2012). The effect of information sharing between lenders on access to credit, cost of credit, and loan performance-Evidence from a credit registry introduction. Journal of Banking \& Finance, 36(11), 3017-3032.

Brehanu, A., \& Fufa, B. (2008). Repayment rate of loans from semi-formal financial institutions among small-scale farmers in Ethiopia: Two-limit Tobit analysis. The Journal of Socio-Economics, 37(6), 2221-2230.

Brown, M., \& Zehnder, C. (2007). Credit reporting, relationship banking, and loan repayment. Journal of Money, Credit and Banking, 39(8), 1883-1918.

Cassar, A., Crowley, L., \& Wydick, B. (2007). The effect of social capital on group loan repayment: Evidence from field experiments. The Economic Journal, 117(517), F85-F106.

Chapman, B., \& Liu, A. Y. (2013). Repayment burdens of student loans for Vietnamese higher education. Economics of Education Review, 37, 298-308.

Chapman, B., \& Lounkaew, K. (2015). An analysis of Stafford loan repayment burdens. Economics of Education Review, 45, 89-102.

Cornett, M. M., Li, L., \& Tehranian, H. (2013). The performance of banks around the receipt and repayment of TARP funds: Over-achievers versus under-achievers. Journal of Banking \& Finance, 37(3), 730-746.

Derban, W. K., Binner, J. M., \& Mullineux, A. (2005). Loan repayment performance in community development finance institutions in the UK. Small Business Economics, 25(4), 319-332.

Godquin, M. (2004). Microfinance repayment performance in Bangladesh: How to improve the allocation of loans by MFIs. World Development, 32(11), 1909-1926.

Graham, J. R., Li, S., \& Qiu, J. (2008). Corporate misreporting and bank loan contracting. Journal of Financial Economics, 89(1), 44-61.

Hill, R. C., \& Sarangi, S. (2012). Repayment performance in group lending: Evidence from Jordan. Journal of Development Economics, 97(2), 404-414.

Im, K., Pesaran, H., \& Shin, Y. (1997). Testing for unit roots in heterogeneous panels. Discussion Paper, University of Cambridge, June.

Lin, J. H., Tsai, J. Y., \& Hung, W. M. (2014). Bank equity risk under bailout programs of loan guarantee and/or equity capital injection. International Review of Economics \& Finance, 31, 263-274.

Majeske, K. D., \& Lauer, T. W. (2013). The bank loan approval decision from multiple perspectives. Expert Systems with Applications, 40(5), 1591-1598. 
Onyenucheya, F., \& Ukoha, O. O. (2007). Loan repayment and credit worthiness of farmers under the Nigerian Agricultural Cooperative and Rural Development Bank (NACRDB). Agricultural Journal, 2(2), 265-270.

Paxton, J., Graham, D., \& Thraen, C. (2000). Modeling group loan repayment behavior: New insights from Burkina Faso. Economic Development and Cultural Change, 48(3), 639-655.

Salleh, M. O., Jaafar, A., \& Ebrahim, M. S. (2014). Can an interest-free credit facility be more efficient than a usurious payday loan?. Journal of Economic Behavior \& Organization, 103, S74-S92.

Sharma, M., \& Zeller, M. (1997). Repayment performance in group-based credit programs in Bangladesh: An empirical analysis. World development, 25(10), 1731-1742.

Vu, T., Do, V., \& Skully, M. (2015). Local versus foreign banks: A home market advantage in loan syndications. International Review of Financial Analysis, 37, 29-39. 